\title{
Embryonic Lethal Mutation
}

National Cancer Institute

\section{Source}

National Cancer Institute. Embryonic Lethal Mutation. NCI Thesaurus. Code C19583.

Any mutation that results in the embryonic death of the organism carrying the mutation. 